\title{
Study of influence of structurizing regims on the properties of structural glass-fiber plastics
}

\author{
O.H.Karandashov ${ }^{1}$, V.L.Avramenko ${ }^{1}$, \\ O.V.Vashchenko ${ }^{2}$, L.F.Podhornaya ${ }^{1}$
}

${ }^{1}$ Department of Technology of Plastics and Biologically Active Polymers, National Technical University "Kharkiv Polytechnic Institute", 21 Bahaliya Str., 61002 Kharkiv, Ukraine

${ }^{2}$ Institute for Scintillation Materials , STC "Institute for Single Crystal", National Academy of Sciences of Ukraine, 60 Nauky Ave., 61001 Kharkiv, Ukraine

Received May 3, 2018

\begin{abstract}
Manufacturing of glass-fiber articles under specified strength characteristics, different ratio of layer thickness to inner diameter and without defects and delaminations is investigated. The influence of technological regimes, degree of curing on the physical and mechanical characteristics of glass-fiber articles was studied. In order to estimate the quality of the obtained articles, and to obtain reliable data on the course of the structuring process, methods of extraction, infrared spectroscopy and differential scanning calorimetry were used.
\end{abstract}

Keywords: physical and mechanical characteristics of glass-fiber.

Исследовано получение стеклопластиковых изделий с различным соотношением толщины стенки и внутреннего диаметра с заданными прочностными характеристиками без дефектов и расслоений. Изучено влияние технологических режимов, степени отверждения на физико-механические характеристики стеклопластиковых изделий. Для оценки качества этих изделий, получения надежных данных о ходе процесса структурирования в работе использованы методы экстракции, инфракрасной спектроскопии и дифференциальной сканирующей калориметрии.

Дослідження впливу технологічних режимів структурування на властивості конструкційних склопластиків. О.Г.Карандашов, ВЛ.Авраленко, О.В.Ващенко, Л.Ф.Подгорнал.

Досліджено отримання склопластикових виробів з різним співвідношенням товщини стінки та внутрішнього діаметра з заданими міцносними характеристиками без дефектів та розшарувань. Вивчено вплив технологічних режимів, ступеня затвердіння на фізико-механічні характеристики склопластикових виробів. Для оцінки якості цих виробів, отримання надійних даних про хід процесу структурування, в роботі використано методи екстракції, інфрачервоної спектроскопії та диференціальної скануючої калориметрії.

\section{Introduction}

Structural glass-fiber is widely used in many industry brunches. Products with different forms and sizes are made of them: pipelines and reaction equipment, building mounds and roofing, bodies of cars, ships, airplanes and rockets, etc. Structural fiber- glass, as construction material, is suitable for obtaining articles with cylindrical shape [1].

Glass-fiber pipes are used in systems of irrigation and land improvement, collectordrainage systems, as main pipelines of firefighting systems and water supply systems, transportation of chemical aggressive environments, oil products, for gas pipelines, 
O.H.Karandashov et al. / Study of influence of ...

Table 1. Technological regimes of glass-fiber articles manufacturing

\begin{tabular}{||c|c|c|c|c|c|c|c||}
\hline \multirow{2}{*}{$\begin{array}{c}\text { Techno- } \\
\text { logical } \\
\text { regimes }\end{array}$} & \multicolumn{2}{|c|}{ Size } & \multicolumn{5}{c|}{ Structuration process parameters } \\
\cline { 2 - 7 } & $\begin{array}{c}\text { Layer } \\
\text { thickness, } \\
\text { mm }\end{array}$ & $\begin{array}{c}\text { Inner } \\
\text { diameter, } \\
\text { mm }\end{array}$ & $\begin{array}{c}\text { Total } \\
\text { time, min }\end{array}$ & $\begin{array}{c}\text { Heating } \\
\text { time, min }\end{array}$ & $\begin{array}{c}\text { Curing } \\
\text { time, min }\end{array}$ & $\begin{array}{c}\text { Curing } \\
\text { temperature, }{ }^{\circ} \mathrm{C}\end{array}$ & $\begin{array}{c}\text { Cooling time, } \\
\text { min }\end{array}$ \\
\hline 1 & 8 & 250 & 24 & 6 & 12 & 160 & 6 \\
2 & 16 & 250 & 24 & 6 & 12 & 170 & 6 \\
3 & 16 & 250 & 35 & 13 & 13 & 140 & 9 \\
4 & 24 & 250 & 35 & 13 & 13 & 150 & 9 \\
5 & 24 & 250 & 60 & 25 & 20 & 120 & 15 \\
\hline
\end{tabular}

water-lifting columns and sewer systems, etc. [2]. Fiberglass pipes manufactured by the cross-fibred longitudinal-circumferential winding (CFLCW) occupy the main place among them. The CFLCW method refers to specific methods for forming glass-fiber products that are characterized by the anisotropic or transversal-isotropic structure [3].

A feature of this method is the limited mobility of the filler when it is combined with the polymer compound, as a result of which the fibrous filler impregnation stage is determinative. Another feature of this process is formation of macrostructure of the fibrous filler in the article with the aim of achieving the required physical and mechanical and performance characteristics. The orientation of the filler is determined by the ratio of substrate rotation and stacker movement rates [4].

Structuring of products takes place on a substrate, special construction of which allows displacing hardened product from its surface with the constant rate. Wherein, duration of structuration process, which consists of duration of polymer compound heating to the curing temperature, curing time and cooling time of hardened polymer compound (finished product), is determined by the substrate length and amounts 20-60 $\mathrm{min}$ [5].

Manufacture of glass-fiber articles with different ratio of the layer thickness to the inner diameter (for different load conditions) leads to change of ratio of the process rate (structuring time) and the temperature regime parameter.

Thus, thin-layer articles with ratio of the layer thickness to the inner diameter less than 0.05 are not inclined to creation of inner defects. Therefore, it is possible to perform rapid heating and cooling of polymer compound, thus leading to increase of the curing part in the structuration process. This contributes to manufacturing of products with the higher curing degree. In addition, a higher temperature can be used to intensify the structuring process.
At increasing of ratio of the layer thickness to the product inner diameter to 0.1 , defects and delaminations can occur. The cause of the defects is origination of inner stresses in the product body. To eliminate them, it is necessary to decrease the heating and cooling rate, increasing their part in the total time of the structuration process, decreasing the curing time. Another way to defects elimination is decrease of the structuration temperature. These technological regime changes lead to decrease of curing degree, what results obtaining low quality articles.

In our work the possibility of obtaining of different glass-fiber articles with different ratio of the layer thickness to the inner diameter with required strength characteristics without defects and delaminations, and also the possibility of estimation the quality of obtained articles by the way of determination of completeness of the curing reaction are investigated. For this purpose, in our work the extraction, infrared spectroscopy (IRS) and differential scanning calorimetry (DSC) methods were used.

\section{Experimental}

For investigations, structural glass-fiber pipes with different ratio of the layer thickness to the inner diameter were manufactured by the CFLCW method at different technological regimes, presented in Table 1 . All glass-fiber pipes are made of epoxy oligomer BE-188 (analog ED-20). The curing was performed with methyl tetrahydrophthalic anhydride (MTHPA) with presence of accelerator DMP-30 (2,4,6-tris (dimethylaminomethyl) phenol). Glass roving (70\% of the total product mass) was used as filler. The laying scheme of the filler had an anisotropy coefficient of 2 .

The glass-fiber pipes (regime 1) with the ratio of the layer thickness to the inner diameter of 0.032 are obtained at the maximal equipment productivity. The time of 
Table 2. The curing degree and failure stress of glass-fiber articles, relatively to the technological regime

\begin{tabular}{|c|c|c|c|c|c||}
\hline Technological regime & 1 & 2 & 3 & 4 & 5 \\
\hline Curing degree, \% & 96,7 & 96,8 & 96,1 & 96,3 & 93,4 \\
Failure stress, MPa & 465 & 320 & 470 & 320 & 455 \\
\hline
\end{tabular}

heating to the curing temperature and the polymer compound cooling time have the least value (6 $\mathrm{min})$, and the curing process time amounts of $12 \mathrm{~min}$ at $160^{\circ} \mathrm{C}$. Inner defects, delaminations were not detected in the obtained articles after the structuration process finish. Then probability of obtaining of products (regime 2) with the ratio of the layer thickness to the inner diameter of 0.064 was investigated, using the previous technological regime. It is established, that it is impossible to repeat the established technological regime at the layer thickness to the inner diameter ratio increase from 0.032 to 0.064 because of increase of curing reaction exothermicity contribution. While curing of products with larger diameter ratio, self-heating was increasing the temperature by $10^{\circ} \mathrm{C}$ because of chemical reaction exothermicity. At higher curing temperature, difficulty in heat removing caused origination of inner defects in the pipe body, and as a result, origination of visible defects and delaminations.

This caused necessity of technological regime change by increase of structuration process total duration, mainly by increase of the polymer compound heating and cooling time, and decrease of the curing temperature in order to reduce influence of reaction exothermicity. Wherein, the curing time practically did not change and amounted $13 \mathrm{~min}$ at $140^{\circ} \mathrm{C}$ instead $12 \mathrm{~min}$ at $160^{\circ} \mathrm{C}$. Curing process intensity decline yielded of products without delaminations, but with reduced structuration reaction completeness.

Analogous investigations were carried out in order to study probability of obtain of fiberglass products with the layer thickness to the inner diameter ratio equal to 0.096. Using the third technological regime, fiberglass products were obtained (regime 4) with visible body delaminations, causes of which are similar to products, obtained by the second regime. In order to eliminate defects in the product, additional reduction of polymer compound heating intensity to the curing temperature and it's cooling after curing were investigated. For this, the structuration temperature was reduced to $120^{\circ} \mathrm{C}$ and the curing durability was increased from 13 to $20 \mathrm{~min}$. Structuration process total duration eventually lasted 60 min. The obtained products didn't have visible defects and delaminations, but had less intensive coloring, pointing at uncompleted structuration reaction. To prove the experiment results, the polymer compound curing degree was investigated for all obtained samples by the extraction method. Simultaneously, influence of curing degree on the mechanic characteristics (the failure stress under transverse tension) was studied.

Ring samples with width of $20 \mathrm{~mm}$ are made of the obtained fiberglass pipes by the mechanical tooling, for determination of the destroying stress at stretching in the transverse (circular) direction accordingly to ISO 8521:2009. Samples are made of these articles by the mechanical tooling, for determination of the structuration degree by the extraction method (Soxhlet apparatus), and fine powder samples for IR spectroscopy and DSC were obtained.

IR spectra were obtained by Spectrum One spectrophotometer (Perkin Elmer) in $\mathrm{KBr}$ in the range of $400-4000 \mathrm{~cm}^{-1}$. DSCthermograms were obtained using MettlerToledo DSC1 microcalorimeter (USA). Milled samples (ab. $10 \mathrm{mg}$ ) were placed into aluminum pans and heated in the range 0 to $200^{\circ} \mathrm{C}$ with scanning rate $10^{\circ} \mathrm{C} / \mathrm{min}$. For sake of comparison, the obtained DSC-profiles were normalized by sample mass.

\section{Results and discussion}

The results of physical and mechanical investigations are presented in Table 2 . It is seen in the Table, that curing temperature decrease affects completeness of structuration reactions more, than increase of the given process duration. Thus, curing temperature decrease (regime 3 ) on $30^{\circ} \mathrm{C}$ relatively to regime 2 leads to reduction of curing degree from 96.8 to $96.1 \%$, regardless increase of the curing time from 12 to $13 \mathrm{~min}$, and the total structuration time from 20 to $35 \mathrm{~min}-$ utes. Similarly, for the products (regime 5), relatively to the products (regime 4), decrease of the curing temperature from 150 to $120^{\circ} \mathrm{C}$ leads to reduction of curing degree from 96.3 to $93.4 \%$, despite increase of the curing time and the total time of the structuration process almost in two times. 
O.H.Karandashov et al. / Study of influence of ...

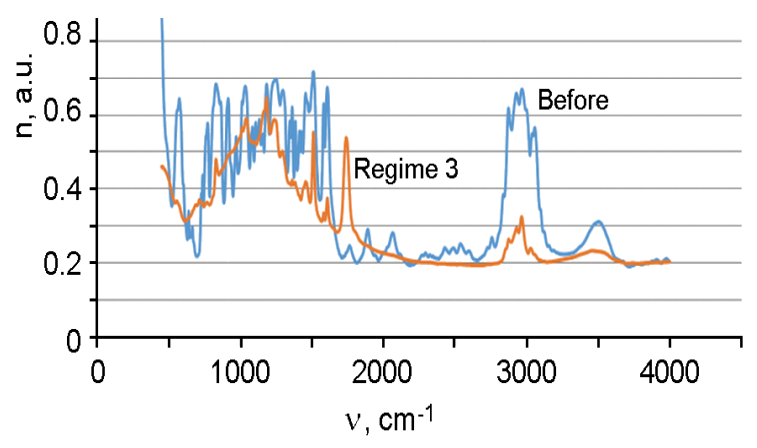

Fig. 1. The graphical dependences of the decimal logarithm of the optical density of the epoxy oligomer before the curing process and the cured glass-fiber plastic articles (regime 3) on the wavelength of the transmitted light.

It is necessary to notice, that despite decrease of curing degree the mechanical properties remain practically unchanged. Thus, in the products (regimes 1, 3, 5), where are no defects and delaminations, the failure stress is located in the range from 450 to $470 \mathrm{MPa}$ and differentiates less than $5 \%$. Delaminations affect the mechanical properties more negatively. Thus, if to compare regimes 2 and 3, and also articles, obtained by regimes 4 and 5, presence of delaminations leads to decrease of failure stress on $30 \%$. It is established that decrease of failure stress depends on size of delaminations, their location and their quantity in cross section.

Further works for improvement of properties of fiberglass products with different ratios of the layer thickness to the inner diameter determine necessity of investigation of new technological regimes with a smooth process flow of epoxy compound structuration. Wherein, use of the extraction method to curing degree determination is problematic because of determination process duration (more than $20 \mathrm{~h}$ ). Thus, we investigated probability of infrared spectroscopy and differential scanning calorimetry for estimation of structuration process completeness and curing degree.

Absorption IR spectra of the fiberglass samples (regimes $1,3,5$ ), and spectrum of epoxy oligomer before curing process beginning are obtained. Graphical dependences of decimal logarithm of optical density on wavelength of incident light, which are presented in Fig. 1 and 2, are obtained after computing. Spectra presented in Fig. 1 show change of the epoxy oligomer structure after curing process finish. It is seen in Fig. 1, characteristic absorption peaks (due deformation vibrations of epoxy cycles bonds at 830, 915 and $3057 \mathrm{~cm}^{-1}$ ) reduced their optical density, what indicates the curing reaction flow by bonding of epoxy groups, quantity of

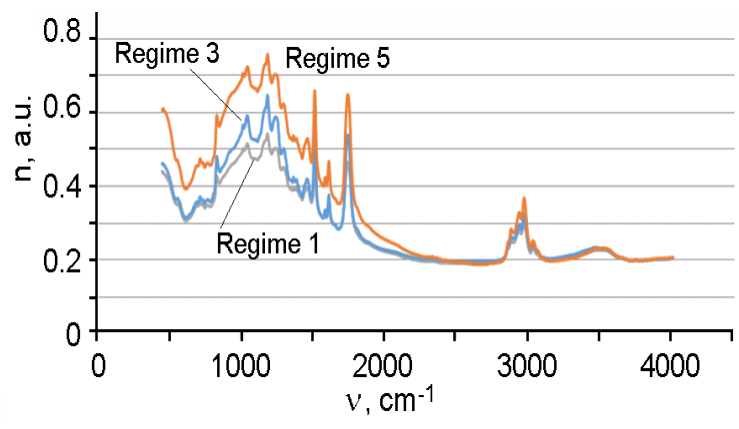

Fig. 2. The graphical dependences of the decimal logarithm of the optical density of glassfiber articles (regimes 1, 3, 5) on the wavelength of absorbed light.

which decrease while reaction process. More detailed information on the completeness of the curing reaction can be obtained by comparing the dependences of the optical density of the cured epoxy compounds of fiberglass products manufactured in different regimes with different curing degrees on the wavelength of the absorbed light. Thus, for technological regimes 1 and 3 , in which the curing degrees are about the same and amount of 96.7 and $96.1 \%$, the values of the optical density at characteristic peaks have very close values. For example, at the wavelength of $3057 \mathrm{~cm}^{-1}$, the optical densities are 0.213 and 0.214 , respectively. And even at the lower curing degree (93.4\%), (regime 5), the optical density at the wavelength of $3057 \mathrm{~cm}^{-1}$ is 0.221 . The same relationships remain also when analyzing the decimal logarithm of the optical density at absorbed light wavelengths of 830 and $915 \mathrm{~cm}^{-1}$.

Thus, using IR spectroscopy, it is possible to more accurately determine the completeness of curing, the decrease of which causes deterioration in the parameters of physical and mechanical properties, and to obtain a characteristic reference graphical dependence, using which one can draw conclusions about the degree of curing.

In addition to IR spectroscopy, for different regimes of curing of glass-fiber pipes, the DSC data were obtained, the results of which are shown in Fig. 3. As it is seen in Fig. 3, for each of the samples in the temperature range from 126 to $130^{\circ} \mathrm{C}$, only one peak appears on the heat flux curve (per unit mass). This temperature range comprises the curing temperature of the epoxy oligomer with the anhydride hardener MTPHA. When this temperature is reached, functional groups, which have not yet reacted for some reasons, are excited. The insignificant enthalpy of this 


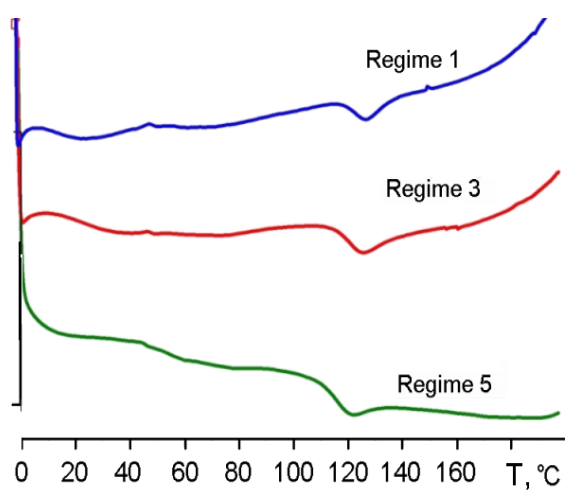

Fig. 3. DSC of glass-fiber articles with different curing degree.

thermal transition (about $0.5 \mathrm{~kJ} / \mathrm{kg}$ ) indicates small quantity of such groups and the inability to correlate the area of the peak with the curing degree of the polymer compound. However, the temperature of this peak reflects the completeness of the curing reaction. Its different values can be explained by the steric effect. For products with the lowest degree of curing (93.4\%), the characteristic peak of the thermal transition corresponds to $126^{\circ} \mathrm{C}$, and for glass-fiber articles with a curing degree of $96.1 \%$ and $96.7 \%-129$ and $130^{\circ} \mathrm{C}$, respectively, due to inhibition of active centers movement and reduction of reaction probability.

Also, it is seen in Fig. 3 that the curves obtained for samples of different technological regimes have different angles of inclination relatively to the abscissa axis. This angle of inclination reflects the temperature dependence of the heat capacity, since the value of the heat flux is proportional to the heat capacity. In terms of this, it is seen that on segments below the peak, samples with a higher curing degree have a larger heat capacity. Above the peak, there is a slight change in the angle of inclination, which corresponds to increase in the heat capacity due to increase in the curing degree. This change in the angle of inclination can be traced not only when the peak is reached, but also after a further stay of the sample at a temperature above the curing temperature. This indicates the further course of the structuring process.

The dependence is revealed that with increasing degree of curing the heat capacity of the material increases, due to decrease in the amount of unreacted material that has a lesser heat capacity. Thus, using the differential scanning calorimetry in the studies, the CFLTW, it is possible to establish criteria (the temperature of thermal transition and the curve angle relatively to the ab- scissa axis), that will correspond to the desired value of the curing degree, with a decrease in which a significant deterioration of the properties appears.

It should be noted, that none of the studied samples have a second characteristic peak that would indicate the transition of the polymer compound from the vitreous to the highly elastic state, which means that the structuring process has passed with the high degree of completeness and in the entire volume.

\section{Conclusions}

As a result of the conducted studies, the cause of the appearance of internal defects in the fiberglass pipes production by the CFLTW method with the ratio of the wall thickness to the inner diameter of more than 0.05 has been established. Technological regimes for the fiberglass pipes production with the ratio of the wall thickness to the inner diameter of $0.032,0.064$ and 0.096 without visible defects and delaminations have been developed. The correspondence of the obtained pipes with different ratio of the wall thickness to the inner diameter to sufficient physical and mechanical parameters was investigated. The effect of internal defects and delaminations on the strength characteristics of articles is considered. The possibility of using the fiberglass pipes polymer compound curing degree as a method for nondestructive testing of the products conformity to the required physical and mechanical properties and the possibility of its determination by IR spectroscopy and DSC methods is studied. The advisability of using IR spectroscopy and DSC to obtain reliable data on the course of the process of structuring was shown, which is extremely important in the manufacture of both conventional and pre-qualitative designs of fiberglass. This opens up wide possibilities for regulating the transversely isotropic structure, strength and operational properties of structural fiberglass.

\section{References}

1. Z.M.Wang, Mechanics of Composite Materials and Structural Mechanics of Composite Materials, China Machine Press, Beijing (1990).

2. J.M.Khatib, Sustainability of Construction Materials, Elsevier, Woodhead Publing (2016).

3. N.Basova, V.Broya, Tehnika Pererabotki Plastmass, Khimiya, Moscow (1985).

4. Patent UA 114679, (2017)

5. O.G.Karandasov, V.L.Avramenko, Chem. Chem. Techn., 11, 61 (2017). 